\title{
Critical Juncture and Nuclear-Power Dependence in Japan: A Historical Institutionalist Analysis
}

\author{
Sung Chull Kim
}

\begin{abstract}
The institution of nuclear power in Japan appears to be drifting; nevertheless it persists. For the past 60 years, conservative politicians, technologists, and electric companies have acted in concert, for different reasons, to achieve a full nuclear fuel cycle: specifically technology for reprocessing and uranium enrichment. Their pursuit has eroded the bottom-line spirit of peaceful use; to be sure, it has been excessively ambitious for Japan's status as a non-nuclear-weapon state. The mastering of the full nuclear fuel cycle has resulted in a competency trap, excluding or delaying development of alternatives to nuclear power. Furthermore, this situation has heightened nuclear power's sunk costs. The critical conjuncture of the March 11, 2011 incident has had a limited impact only. Anti-nuclear activists, the weakest concerned actor, try to dramatize their movement for "exit from nuclear," but they have failed to bring about electoral changes.
\end{abstract}

Keywords nuclear power, institution, actors, spirit of peaceful use, full nuclear fuel cycle

\section{Introduction}

The incident at Fukushima on March 11, 2011 (hereafter the March 11 incident) was a critical juncture for Japan's nuclear power policy and its related industries. Not only did the incident produce enormous impact on the health and human security of nearby residents, but it also raised questions about nuclear safety, energy policy, and environmental degradation. Indeed, the March 11 incident immediately brought about widespread public fear, particularly because the government and the Tokyo Electric Power Company (TEPCO) concealed information related to both the incident and the resulting radioactive contamination of the air, ocean, and soil, for at least three months. Later, as all nuclear reactors were temporarily shut down, in May 2012, for safety checks, anti-nuclear power rallies mushroomed to demand a permanent elimination of 
the government's nuclear energy program. The rallies were followed by a tug of war between Tokyo and the three prefectures in the Kansai area over whether or not operation of the Oi nuclear plant in Fukui Prefecture should be resumed. However, the March 11 incident and the subsequent anti-nuclear power rallies had only a limited impact. The central government resumed operation of the Oi power plant in June. Furthermore, in the general election held in December 2012, the politicians advocating "exit from nuclear" failed to obtain voters' support. The election result was a landslide victory of the Liberal Democratic Party (LDP), ending up with the inauguration of a cabinet led by Abe Shinzo, pro-nuclear LDP leader. The ongoing policy debate focuses on safety, not the question of whether or not to keep nuclear power.

Why did this unprecedented shock, a real critical juncture, fail to bring about a change in the government's policy on nuclear power? In other words, why does nuclear power remain alive in Japan in spite of the disaster and the mounting criticism? In addressing these questions, this article examines what aims the main actors relevant to nuclear power have pursued while coping with important international and domestic junctures, and how the spirit of peaceful use has been eroded. In fact, the most dominant actors, even if with different motivations, have come together to support the persistence of the institution of nuclear power. Despite the March 11 incident's depressing impact, they still remain supportive of the reliance on nuclear power. Anti-nuclear activists have led rallies to challenge the value of energy independence based, inter alia, on nuclear power. However, conservative politicians, encroaching upon the spirit of the so-called peaceful use of nuclear power, remain aligned with nine electric companies and officials from the Ministry of Economy, Trade, and Industry (METI), formerly the Ministry of International Trade and Industry (MITI). The institution of nuclear power is not exhausted yet. It seems to be drifting, but it persists.

\section{Nuclear Power as an Institution}

Emerging studies on the March 11 incident either analyze different reasons behind the nuclear disaster, criticize the government's response to the incident, or propose alternative energy policies. It is possible to group these studies as follows. First, some studies focus on the relations between the central government and the local governments hosting the nuclear plants (Dusinberre and Aldrich 2011; Kaneko 2012; Onitsuka 2012). Second, other studies reveal the triangular relations between the government, politicians, and electric companies (Nanao 2011; Yoshioka 2011). Despite the differences of explanations concerning the roles of the different groups, they commonly point out reciprocal relations between the three actors. Third, a few studies highlight technological nationalism (Penny 2012). Indeed technological nationalism and national grandeur appear in 
Japanese literature such as that of Toyoda Arisune (2012) praising Japan's nuclear technology. Finally, reexamining the underestimated role of the United States, some recent studies uncover U.S. pressure on Japan to adopt nuclear power in the 1950s (Arima 2008; Zwigenberg 2012).

The above-mentioned studies are worthy to note, but they offer reductionist explanations. Each study highlights a single factor to account for the enduring complex phenomenon of support for nuclear power. To understand the reasons why Japan's nuclear power policy has been maintained, particularly after such a critical juncture, one needs to scrutinize the ways in which diverse stakeholders act for or against, it. One also needs to examine the consequences of their actions in the long run, particularly the gradual erosion of either the values or the spirit embedded in the adoption of nuclear power.

To be sure, nuclear power is an institution. As opposed to technological determinism, I argue that the development of technology is not a mere consequence of inner logic. Its trajectory is shaped by people and by society. In this respect, there is no pure technology (Bijker and Law 1992, 3; Adria 2010). Nuclear technology, especially, is socially shaped.

In considering nuclear power as an institution, I examine both internal dynamics and the relationship between the institution and the outside world. Early institutionalist theories failed to notice this point. As Fioretos (2011) and Thelen (2004) aptly point out, early theories emphasized the lock-in effect: the institution's initial control over the trajectory that followed. The early studies presumed that there is automaticity in the logic of institutional persistence; they believed that an institution is punctuated only by an external shock. In other words, those studies concentrated on the internal inertia of persistence and the external determinant of the institution's trajectory; they overlooked internal dynamics that could channel the mode of change at the particular time of an external shock. In contrast, recent works tackle this problem-how institutional persistence can coexist with gradual changes within the institution (Pierson 2000; Ikenberry 2001; Pierson 2004; Thelen 2004; Mahoney and Thelen 2010). For example, the work of Mahoney and Thelen (2010) sheds light on the relationship between internal dynamics, institutional change, and external shocks. According to them, external shocks cannot bring about the institution's breakdown or displacement unless internal dynamics have exhausted the values and spirit embedded in the institution. At that particular time, the institution's breakdown depends on the extent to which the mode of relationship between individual actors (or groups) within the institution has encroached upon its values and spirit. I argue that if the institution is not ready to be changed, an external shock has little impact on it. This logic of institutional persistence and change can be applied to nuclear power in Japan. Here I need to elaborate some related notions, as follows.

Value and Spirit: At the initial stage of Japan's development of nuclear power, 
that is, in the early 1950s, the relevant actors' bottom-line value was energy security. Also, they referred to the term "peaceful use" of nuclear technology as the spirit. The bottom-line value represents something worthy of pursuit to actors who are promoting or associated with nuclear power. The spirit refers to an initial force legitimizing and controlling the actors' pursuit of the values. It is worth noting that the value and the spirit may evolve over time. In the case of Japan, the value of energy security has been upheld without any change, whereas the spirit of peaceful use has been eroded gradually but seriously. The spirit has been affected by inherent characteristics of nuclear technology. Namely, nuclear technology can serve two purposes: weapons development and energy use. These characteristics have fostered ambiguity whereby diverse actors have competed, or coalesced, or supported one another for different reasons. In fact, actors have upheld different expectations in regards to nuclear power thus affecting the spirit of peaceful use.

Actors: There are four main actors-conservative politicians, technologists, electric companies, and anti-nuclear activists. First, conservative politicians are important figures either in the cabinet or in the legislature. Despite power shifts from the LDP to the Democratic Party of Japan (DPJ) in 2009 and from DPJ to LDP in 2012, the mainstream political trend in Japan has remained intact. Personal motivations of the politicians to support nuclear power have differed: Some of them have supported it in order to accumulate all potential technological capabilities; others have done so for the sake of technological independence; and still others may have supported it for both reasons. For all of them, however, energy security has been the bottom-line value. Second, technologists are officials and experts from MITI, later METI, and from the Japan Science and Technology Agency (JSTA). They have been deeply involved in the decisionmaking related to nuclear power. These government organizations and officials have not only sanctioned electric companies' business ventures, but they have also acted as "guarantors" of the national nuclear energy project (Dauvergne 1993). Conservative politicians and the technologists have promoted nuclear power as kokusaku, meaning state-sponsored policy. Third, electric companies are supported by kokusaku; the government has protected electric companies' business interests. The government has provided them with a public relations campaign so that the companies have been able to find new sites to build nuclear plants. For instance, the public relations campaign funding reached an average of 10 billion Japanese yen annually at the end of the 1980s. In return, the companies have kept kokusaku alive by sustaining local economies, particularly by paying taxes as well as official and unofficial subsidies (Yoshida 2000, 62-3). Finally, antinuclear activists are not a unified group. Most of the activists have focused on the abolition of nuclear weapons, and thus they have mostly remained mute on the peaceful use of nuclear technology. Only a small segment of the anti-nuclear activists has advocated anti-nuclear power, and their weak standing has long 
been abraded by the government's coercive tactics (Aldrich 2008). Only after the March 11 incident did a strong group advocating "exit from nuclear" emerge.

Roles: In terms of the roles played by the actors, there are promoters, symbionts, insurgents, and innovators. First, promoters are those who actively push the program. They support not only the value of energy security but also the spirit of peaceful use, at least at face value. The electric companies have been the most important promoters because they have benefited directly from the institution. They have been willing to pay some costs in order to collect better returns in the end. Conservative politicians have also been crucial promoters from the beginning. They have been basically pro-American and anti-communist; they have aligned themselves with the U.S. policy of nuclear-technology transfer to Japan. Second, symbionts are those who take part in the institution, but their commitment lies in their enthusiasm for the byproducts of the institutional existence and burgeoning. More important, their interests are not always compatible with the spirit of peaceful use. In Japan, conservative politicians have been promoters in most instances; at the same time, some of the top rightwing politicians have been symbionts. They have taken advantage of a booming nuclear energy industry, on the one hand, and have pursued a full nuclear fuel cycle that may breach the taboo of nuclear armament, on the other (Suzuki 2006). Third, insurgents are those who seriously "reject the institutional status quo" and earnestly seek to replace the institution (Mahoney and Thelen 2010, 23-4). But they can never achieve their objective by themselves; other actors must make concerted efforts for the same objective. In Japan, the insurgents are represented by the activists. Finally, innovators are those who try to correct the existing practices and restore the early value and spirit. Notably, their efforts can hardly be successful because of the already well-established practices. Innovators differ from insurgents in the sense that the former adhere to and act for the persistence of the institution. In Japan a small group of officials in the government were the innovators who made attempts to liberalize the electric industry between the end of the 1990s and the first half of the 2000s.

Junctures: Several important events occurred in Japan and around the world even before the March 11 incident in Fukushima. These events may be called "important junctures," in comparison to the critical juncture, the March 11 incident. That incident has changed dramatically the public perception of nuclear power; its impact on internal dynamics has been critical. It is, however, noteworthy that there were important junctures prior to the March 11 incident. Each important juncture has had its own unique impact on the institution. The important junctures are the pressure by the United States in the early 1950s, the oil crisis in 1973, the Chernobyl incident in 1986, and the accidents in Japan in the mid-1990s. With the exception of the accidents in the mid-1990s and the March 11 incident, these important junctures mostly contributed to reinforcing the existing institution of nuclear power. 
Table 1. Stages of Internal Dynamics

\begin{tabular}{cccccc}
\hline \hline & $\begin{array}{c}\text { Institutional } \\
\text { emergence, }\end{array}$ & $\begin{array}{c}\text { Institutional } \\
\text { take-off, } \\
1953-1972\end{array}$ & $\begin{array}{c}\text { Institutional } \\
\text { peak, } \\
1973-1985\end{array}$ & $\begin{array}{c}\text { Institutional } \\
\text { stagnation, } \\
1986-1994\end{array}$ & $\begin{array}{c}\text { Institutional } \\
\text { drift, } \\
\text { pron-2010 }\end{array}$ \\
\hline $\begin{array}{c}\text { Conservative } \\
\text { politicians }\end{array}$ & promoters & $\begin{array}{c}\text { promoters } \\
\text { symbionts }\end{array}$ & $\begin{array}{c}\text { promoters } \\
\text { symbionts }\end{array}$ & $\begin{array}{c}\text { promoters } \\
\text { symbionts }\end{array}$ & $\begin{array}{c}\text { promoters } \\
\text { symbionts } \\
\text { (insurgents) }\end{array}$ \\
\hline Technologists & promoters & promoters & promoters & $\begin{array}{c}\text { promoters } \\
\text { (innovators) }\end{array}$ & promoters \\
\hline $\begin{array}{c}\text { Electric } \\
\text { companies }\end{array}$ & & promoters & promoters & promoters & promoters \\
\hline $\begin{array}{c}\text { Anti-nuclear } \\
\text { activists }\end{array}$ & (insurgents) & & (insurgents) & & insurgents \\
\hline
\end{tabular}

Note: Actor in parentheses retains weak standing.

Internal Dynamics: At each important juncture, every actor's response has changed slightly (see Table 1). Inasmuch as preferences and capacities differ among the actors, the ways in which they cope with the junctures differ from one another. Sometimes they passively react, and sometimes they actively manipulate domestic or international events to achieve their own objectives. For instance, at the initial stage, conservative politicians used the American call for "Atoms for Peace" to implement the idea of the nuclear energy project either for personal political purposes or because of their commitment to national grandeur. In the stagnating years, some of the politicians encroached upon the spirit of peaceful use. Calling public attention to nuclear weapons development by North Korea, they openly challenged the spirit. Technologists in the government made nuclear power a state-sponsored industry; they supported and supervised the electric companies; they were committed to achieving independent nuclear power and the full fuel cycle. In response to a series of accidents in the mid-1990s, they became the innovators who cared about institutional persistence. The electric companies and manufacturers, related to this business, continued to promote nuclear power. But their role changed over time: commercialization in the formative years, contributing to technological independence in the burgeoning years, and active campaigners in the stagnating years. The anti-nuclear activists mostly accepted the value of nuclear power, focusing on the weaponry side of that technology. But they opposed the technology itself in various ways when three events took place: the exposure of the fishing boat Lucky Dragon No. 5 to a U.S. nuclear test in 1954, the Chernobyl incident in 1986, and the March 11 incident in 2011. In sum, within a certain range each actor's role and composition have gradually changed over time; particularly, the ways in which dominant actors contribute to institutional persistence have gradually shifted. 


\section{Institutional Emergence, 1953-1972}

In this formative stage, the prime promoter was U.S. President Eisenhower who gave legitimacy to the so-called peaceful use of nuclear power. With his "Atoms for Peace" speech at the UN General Assembly in December 1953, the U.S. government urged Japan to adopt the nuclear energy project. As critics argue, Eisenhower delivered the speech as part of the U.S. containment strategy toward the Soviet Union (Tanaka and Kuznick 2011). In fact, both camps in the East and the West made efforts to proliferate or transfer nuclear technology to their own allies. The Soviet Union delivered it to China, Eastern European allies and North Korea. Meanwhile, the United States and the United Kingdom gave the technology to their allies, including Japan and South Korea.

Without political partners in the hosting countries, the American technology transfer might have failed. In Japan, the United States partnered with Nakasone Yasuhiro and Shoriki Matsutaro. Nakasone, who later became prime minister in 1982, succeeded for the first time in securing a budget in the Diet, in March 1954, for the purpose of atomic research. As an anti-communist and an advocate of remilitarization, Nakasone called for a nuclear power project in 1959, during his tenure as the director of the Japan Science and Technology Agency. With his support, Japan succeeded in producing over $90 \%$ enriched uranium in a research laboratory in 1962 (Yamaoka 2011). Just as the converging of interests toward national grandeur between nuclear engineers and policy makers led to the establishment of a techno-political regime in France (Hecht 2009), so Nakasone's drive for technological nationalism, combined with the efforts of nuclear engineers, brought about acquisition of independent nuclear technology in Japan.

Furthermore, a recent study based on declassified documents reveals that the U.S. government approached Shoriki, the president of Yomiuri Shimbun and Nihon Terebi, in order to propagate the peaceful use of nuclear power. The United States provided Shoriki with a 10 million dollar loan for Nihon Terebi; in response, Shoriki used the media as an instrument to propagate the peaceful use of nuclear energy. The United States approached him for several reasons. He was a staunch anti-communist, just as Nakasone was. Also, unlike the public broadcasting company NHK, Yomiuri Shimbun and Nihon Terebi did not have a strong progressive labor union (Arima 2008).

The collaboration between the U.S. government and Shoriki, above all, aimed at watering down the Japanese people's anti-nuclear sentiment that had sprung up after the Lucky Dragon incident of March 1954, when a Japanese fishing boat was exposed to the U.S. hydrogen bomb test at Bikini Atoll in the Marshall Islands. Angered by the death of a crew member, 32 million Japanese signed up to join the anti-nuclear movement. This resulted in the formation of 
the Japan Council against Atomic and Hydrogen Bombs (Gensuikyo) in 1955, which in turn facilitated the establishment of the Citizens' Nuclear Information Center (Genshiryoku Shiryo Jyohositsu) two decades later (Wittner 1997, 153-56; Dusinberre and Aldrich 2011, 687).

Nevertheless, the United States launched an extensive campaign to promote the use of civilian nuclear industry in foreign countries. In this context, the president of General Dynamics, John Hopkins, visited Japan in December 1954. Hopkins was the person who once called the transfer of nuclear power to allies the "Atomic Marshall Plan" (Zwigenberg 2012). In Japan, Shoriki played an active role in rallying support for nuclear power, particularly at the Atoms for Peace exhibition in 1955. Using his media as instruments of propaganda, Shoriki depicted nuclear power energy as an "industrial revolution through atoms." As a result, the total number of visitors to the exhibition reached 350,000 in November and December 1955. The most important impact must have been the "psychological effect" of such a large number (Arima 2008, 120). In May 1956, a more striking event took place: An Atoms for Peace exhibition was held in Hiroshima, one of the two cities devastated by the atomic bombings. One hundred thousand people visited the exhibition and accepted the idea that nuclear energy could be used for civilian purposes.

The collaboration between the U.S. government and the conservative Japanese politicians was a success. The strong anti-nuclear sentiment, exposed by the Lucky Dragon incident, dissipated significantly. Anti-nuclear activists, and citizens more broadly, became silent over the question of nuclear power.

Consequently, postwar Japan entered an era of nuclear power. The government created the Atomic Energy Commission (AEC) in the prime minister's office in 1956; the AEC became the highest legal decision-making body with regard to nuclear policy. The legislature passed the Basic Law on Atomic Power in December 1955, which entered into effect in 1956. Also, the government established the Japan Science and Technology Agency (JSTA) and the Japan Atomic Power Company in 1957 to introduce nuclear technology from the United Kingdom. The consequences were remarkable. The two major electric companies-TEPCO and the Kansai Electric Power Company (KEPCO)-were able to secure contracts with General Electric and Westinghouse, respectively, to build nuclear reactors. In 1963 and 1964, they adopted the American light-water reactor as the model for Japanese reactors. In 1966, the Tokaimura power plant started operation with a relatively small-scale 165 megawatts. In 1970, KEPCO started operation of the Mihama power plant, and in 1971, TEPCO began to operate the Fukushima Daiichi power plant, where the unprecedented nuclear disaster occurred in 2011. 


\section{Institutional Take-off, 1973-1985}

With China's nuclear test in 1964, and India's test in 1974, the United States tightened the international non-proliferation regime and became wary of transfer of nuclear technology to allies. Exceptionally, however, Japan was allowed to expand its international connections regarding nuclear technology (Iida 2011; Yoshioka 2011). No doubt the oil crises of 1973 and 1979 contributed to the Japanese pursuit of nuclear power. In the 1950s and the 1960s, Japan's energy industry, despite its entering the nuclear age, switched from using coal to oil to produce electricity (Tolliday 2012, 6). But the oil crises, which can be regarded as external shocks, became significant facilitators, if not driving forces, for the development of nuclear power.

There were active supporters of this development at that stage. First, observing the global trend toward nuclear armament, conservative politicians came to believe that Japan should develop a full nuclear fuel cycle. They could not openly discuss the development of nuclear weapons because Japanese society was still very allergic to the idea. However, they considered it necessary to develop all potential technology related to weapons development as well as to the production of electricity (NHK E-TV 2012; Suzuki 2006). In this sense, the conservative politicians were symbionts as well; they disregarded the original spirit of peaceful use and instead valued other purposes of the technological development, whereas they continuously supported the bottom-line value of energy security and energy independence.

Second, technologists at MITI had different reasons to gear up nuclear power. With much-trumpeted confidence gained from previous successes, they became a driving force behind the nuclear energy project. Supported by U.S.-Japan technological cooperation, they managed to turn the nuclear industry into a state-sponsored industry where there was no market competition. MITI granted each electric company the monopoly of a region and allowed it to set electricity price. In this way MITI and the electric companies established a relationship based on mutual protection and loyalty (Nanao 2011, 86-92).

Soon after the world oil crisis of October 1973, MITI established a new organization to deal with the commercialization and industrialization of nuclear power technology: the Agency for Natural Resources and Energy (ANRE). MITI also projected a long-term plan to explore resources, nuclear power being the main one. With its leading capacity and a well-functioning ANRE, MITI became a powerful and influential organization with regard to nuclear power, although the Atomic Energy Commission formally remained the highest decision-making body (Yoshioka 2011).

Faced with another oil crisis in 1979, MITI established the New Energy Development Organization (NEDO) in October 1980. In 1988, the name 
Figure 1. Number of Reactors

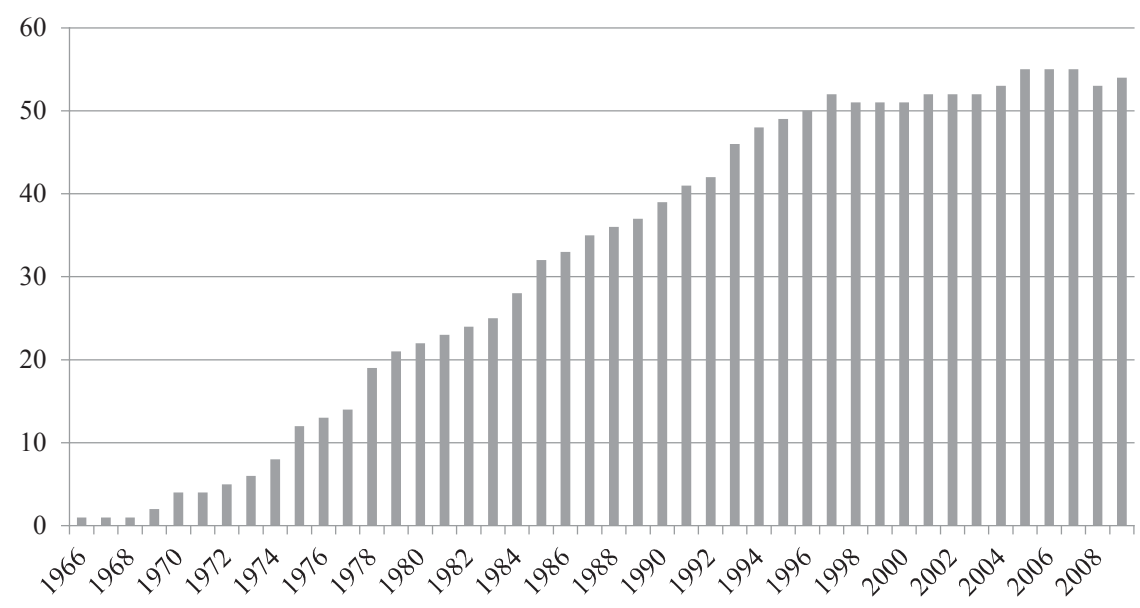

Source: Yoshioka (2011), 144.

was changed to the New Energy and Industrial Technology Development Organization. NEDO originally planned to spend its budget not only on nuclear power but also on other diversified sources of energy, such as solar panels, wind turbines, and thermal energy. To the officials from MITI and NEDO, however, nuclear power remained the most promising source. Since they expected high initial costs in developing the other energy sources (Nanao 2011, 76-7), technologists from MITI and NEDO became strong advocates of nuclear power during a period of prevailing uncertainty about alternative sources of energy.

Third, the electric companies, taking advantage of the state-sponsored policy, became the strongest promoters of nuclear power. In 1974, the government initiated the legalization of three subsidies to the localities hosting nuclear plants: the Subsidy for the Promotion of Locating Power Plants, the Special Subsidy for the Location, and the Subsidy for Safety Measures of Nuclear Plants. The largest portion of the subsidies was poured into the localities selected for locating the plants and building reactors and related facilities. The electric companies took part in the government's subsidy scheme. In fact, a significant amount of funding for the government subsidies came from the taxes paid by the companies. The local governments would then use these subsidies to construct and repair infrastructure and welfare facilities such as bridges, water supply facilities, swimming pools in elementary schools, libraries, tennis courts, local museums, and tourist centers. After the start of the operation, the electric companies financially supported hosting cities by paying local taxes, such as property tax and the nuclear fuel tax (Nanao 2011, 146-47). These taxes constituted a substantial part of the budgets of local governments, ranging from $80 \%$ at the lowest to $95 \%$ at the highest. In this context, the local governments became reliant on the money 
related to nuclear power plants. The money became "sweet candy" (ametama), meaning difficult to discontinue, or was likened to an "oxygen mask" without which a patient cannot live (Kaneko 2012, 136-43).

To be sure, the electric companies did not make the local cities rich. Usually the local cities that accommodated nuclear plants originally suffered from poverty and depopulation. Particularly they lacked a young and working population. In part, the plants created jobs and slowed depopulation. For instance, in a city hosting a nuclear plant in the Fukui Prefecture, one out of four jobs was related to the power plant. The nuclear plants, however, drove out other businesses because of the latter's environmental concerns, a situation that eventually impoverished these cities (Dauvergne 1993, 587; Dusinberre and Aldrich 2011, 689-90).

\section{Institutional Peak, 1986-1994}

This stage is characterized by continuous growth of nuclear power both in terms of remarkable technological advances and the number of power plants. This situation in Japan was the opposite of that in the American and European cases.

The Three Mile Island accident in 1979 led to the suspension of building of nuclear reactors in the United States for more than two decades (Furber, Warf, and Plotkin 2008). The Reagan administration, inaugurated in 1981, tried to reinvigorate the nuclear industry, but the electric companies were reluctant to invest in building new plants because of strict safeguards and regulations that raised construction costs. The Chernobyl incident of 1986 brought about a shock to Europe. As the radioactive material spread to the European continent, public confidence in nuclear power seriously eroded. In Japan, public suspicion about nuclear energy also deepened. Concerned scholars' writings contributed to this trend. A prime example was that of Hirose Takashi who wrote Kikenna hanashi (Dangerous Story) in 1987, in which he revealed the dangerous aspects of nuclear power and nuclear waste. It seemed that a fragmented anti-nuclear power activism turned into a more integrated opposition. At the end of the 1980s and in the beginning of the 1990s, citizen activism, related to the nuclear power issue, led to referendums and lawsuits in Hokkaido and Fukui Prefecture to halt the construction of a new plant and to reclaim their "rights to safety" (Cyranoski 2001, 729). One notable impact of the Chernobyl incident on Japan was the rise of the cost for locating new plants and the delay of their construction. However, the negative impact was not fundamentally detrimental. The government and the electric companies undertook unified and concerted actions, particularly through expensive public relations campaigns, to gain the confidence of local people (Dauvergne 1993, 580-82).

Japanese nuclear power reached a peak between 1986 and 1994. As shown in Figure 1, nuclear power plants continued to be built until the mid-1990s. 
More important, Japan entered the age of independent nuclear power. Japanese technology reached the point of practical use of reprocessing and enrichment in the industry. Japan's independent nuclear power status should be attributed to the continuous work of supporters who paved the way for more than three decades: conservative politicians such as Nakasone and Shoriki, electric companies, and technologists in the government.

In relation to achieving an independent nuclear power industry, one remaining technology that Japan desperately sought to acquire was the fast breeder reactor (FBR). However, this went against the worldwide trend. The FBR was considered an ideal reactor to increase the quantity of plutonium, which can be used both as a fuel and as a crucial ingredient of an atomic bomb. At the end of the 1970s, most Western nations, including the United States, stopped the development of FBRs. Furthermore, the U.S. government stopped reprocessing spent fuel because of higher projected cost than disposal. In the early 1990s, remaining nations such as the United Kingdom, France, and Germany terminated their FBR programs (Tolliday 2012, 18). To construct an FBR, a critical problem should be solved. The coolant material, sodium, increases the doubling time and power, but the enhanced speed and power necessarily bring about safety problems. Breeding and safety are contradictory, and thus all the issues related to the FBR are practically impossible to solve (Furber, Warf, and Plotkin 2008, 46-8). Nevertheless, the United States remained silent on Japan's plan for constructing FBRs and supported Japan's pursuit of the full nuclear fuel cycle (Lidsky and Miller 2002; McCormack 2011).

In October 1985, the Japan Atomic Energy Agency started the construction of the Monju FBR in Tsuruga City in Fukui Prefecture. But the FBR later proved not to be a useful prototype in an economic sense, because its construction cost was five times that of a conventional reactor (Cyranoski 2010; Koide 2011). The Japanese adherence to the FBR was a typical case of competency trap, which was irrelevant to efficiency. According to March and Olsen (1989), competency trap means the following of old grooves, a situation that slows down the pace of efforts to accommodate inputs requiring innovative changes. Japan's desire to achieve technological independence with nuclear power-and the overly ambitious full nuclear fuel cycle-virtually disregarded efficiency.

Meanwhile, the Japanese technologists successfully struck an important deal with the United States, in November 1987. At talks on revision of the nuclear energy cooperation agreement, Japan finally secured U.S. approval for "advance, long-term consent for reprocessing, transfers, alteration, and storage of nuclear material" (Reagan 1987). This new agreement replaced the 1968 agreement according to which Japan was to seek U.S. consent on a case-by-case basis. With this new agreement, MITI was able to proceed with the reprocessing program and the full nuclear fuel cycle.

Again, the Japanese companies acted as influential promoters. In order to 
master the full nuclear fuel cycle, the nine electric companies jointly established a proxy company, Japan Nuclear Fuel Limited (JNFL), in Rokkasho, Aomori Prefecture, in 1985, and in turn the JNFL started construction of a low radioactive waste storage facility and an uranium enrichment plant. Both facilities began operations in 1992. Also, the JNFL built a huge reprocessing plant in 1993, which had greater capacity than that of the Tokai plant. If the plant operates fully, it will process 800 tons of nuclear waste to produce one ton of plutonium annually (Burnie and Smith 2001, 58; Dauvergne 1993, 586). The JNFL project in Rokkasho was one of the largest and most ambitious industrial projects in Japan. Rokkasho became the "Atomic Mecca," as Nakasone recalled (Yamaoka 2011, 168).

The manufacturing companies succeeded in developing their own reactor model and related facilities and actively sought markets abroad. Mitsubishi Heavy Industry was the forerunner in this field. Mitsubishi, which entered the nuclear business in 1955, produced its own brand, the pressurized water reactor. Although it maintained the license contract with its American partner Westinghouse, Mitsubishi inserted more than $90 \%$ of its technology into the PWR model. Also, Mitsubishi possessed the technology needed for all processes required for designing, developing, and building crucial components of the power plant, such as turbines and measuring instruments. Mitsubishi exported these components to Europe, the United States and China. Surprisingly, the company alone took $40 \%$ of shares in the nuclear-related market in the United States (Nanao 2011, 121-24).

Conservative politicians played their role as both promoters and symbionts. Witnessing the intensified nuclear arms race between the United States and the Soviet Union in the 1980s, the conservative politicians preferred strengthening Japan's nuclear capability. In particular, Prime Minister Nakasone (1982-1987) gave priority to acquiring independent nuclear technology as part of Japan's defense policy (Yamaoka 2011, 184-85). He once argued for the need for postwar Japan's remilitarization, and he was a longtime proponent of nuclear technological nationalism. In this regard, he might have had in mind the capability for weapons development.

On the other hand, the anti-nuclear activists who advocated the abolition of nuclear weapons, for the most part, did not oppose the peaceful use of nuclear technology. The only exception was their momentary alignment with a small segment of anti-nuclear power activists after the Chernobyl incident. Furthermore, with the disintegration of the Soviet Union in 1991, the activists hoped that their dream of eliminating all weapons of mass destruction would be realized. This was so, in their eyes, because the West also lost the logic of possessing, developing, and deploying such weapons in a world where there was no enemy.

To sum up, of all the countries that use nuclear power as a source of energy, 
Japan became the only country to possess a full nuclear fuel cycle: reprocessing, enrichment, and the fast breeder reactor. The state-sponsored nuclear industry survived the unprecedented nuclear disaster in Chernobyl and its worldwide sequels. Also, Japan succeeded in revising the U.S.-Japan Nuclear Energy Cooperation Agreement, thus attaining a unique and privileged status in the nuclear non-proliferation regime.

\section{Institutional Stagnation, 1995-2010}

In the 1990s, several nuclear plant accidents occurred in Japan one after the other. In December 1995, a few months after its first operation, the Monju FBR leaked liquid sodium used as a coolant, an accident that eventually caused a fire. The more serious problem was that the headquarters tried to conceal the accident and delayed reporting it. Monju was expected to start commercial operation before 2050. In March 1997, there was another accident at the Tokai reprocessing plant. A fire occurred at the asphalt solidification factory; the workers at the plant made a false report concealing the spread of radioactive materials. In September 1999, another fatal accident occurred at Japan Nuclear Fuel Conversion Co. (JCO), which had been established in 1979 on the rising trend of nuclear power in Japan. Two workers died of exposure to radiation, and 667 people were exposed to radiation in varying degrees (McCormack 2011, 269-71).

Obviously, all these accidents produced a negative public perception about the use of nuclear energy. Particularly, the Tokai accident was followed by severe criticism of the Power Reactor and Nuclear Fuel Development Corporation (PNC). Since its establishment in 1967, the PNC has been the centerpiece of the nuclear fuel cycle. It was involved in the development of the FBR and new models of nuclear reactors; thus it possessed a lot of high-level radioactive waste, and so operated its own reprocessing plant.

Also, the JCO accident resulted in criticism of the Japan Science and Technology Agency (JSTA), which had been the headquarters of the administration and management of the JCO and other nuclear research. Eventually the JSTA was dissolved and absorbed into the Ministry of Education, Culture, Sports, Science and Technology, when an organizational restructuring of the government took place in 2001. The dissolution of the JSTA meant further empowerment of METI, formerly MITI, and strengthened the alignment between METI and the electric companies (Yamaoka 2011, 194).

Here it is interesting to observe the internal dynamics of the nuclear power institution. First, the conservative politicians continued to play two different roles: promoters and symbionts. As promoters who sustained the value of energy security, they made efforts to respond to the public disappointment by taking initiatives and actions in the Diet to restructure the government's organization, 
as described above. It is, however, fair to say that the restructuring could not guarantee efficiency with regard to the operation of nuclear power. Rather, the restructuring was a mere competency trap. Those politicians' effort was nothing more than a merger of the nuclear power-related organizations. It was not intended to alter the excessively ambitious goal: full nuclear fuel cycle.

As symbionts, some top conservative politicians seriously watered down the spirit of peaceful use. They took advantage of the achieved technology to openly express their ambition for Japan to become a potential nuclear weapons state. Witnessing North Korean nuclear tests in October 2006 and May 2009, hawkish politicians, such as Nakagawa Shoichi and Aso Taro, broke the longstanding taboo in Japan. They argued that the possibility of nuclear armament should be discussed in the public sphere (Kim 2013, 92). The nuclear option is not likely to achieve public consensus in the short run, because of the multiplicity of actors with different interests in regards to the future path for the use of the technology (Hymans 2011). But it is no longer taboo to discuss it in political circles and with the support of conservative academics (Chanlett-Avery and Nikitin 2009). Indeed, the long submerged intention of those conservative politicians finally emerged to the surface.

Second, the technologists and the electric companies remained strong promoters, expanding their collusive relationship. With the dissolution of the JSTA, METI and its auxiliary organizations retained more power than before. Their relationships with electric companies became more collusive than ever. A typical collusive practice was amakudari, which literally means descending from heaven to earth, but indeed sarcastically implies the ties between supervising bureaucrats and businesses. In other words, retired officials took positions with the electric companies and play a bridging role between the government and the companies.

There was another reason why technologists promoted nuclear power. They used Japan's nuclear technology as an instrument of a new development strategy in times of prolonged economic stagnation. The officials in METI actively promoted the need to export their nuclear technology. In June 2010, Japan established an agreement for atomic energy cooperation with India. This agreement was a kind of follow-up agreement after the U.S.-India nuclear energy accord of July 2005, which recognized India as a nuclear weapons state without formal recognition of that status (Paul 2007, 846). To be sure, the Japan-India agreement breached Japan's official policy of non-proliferation, because India developed atomic bombs and tested them while refusing to enter the NonProliferation Treaty. The technologists' efforts to export nuclear technology became more apparent when Japan signed another nuclear energy cooperation agreement with Vietnam, in January 2011, two months before the March 11 Fukushima incident. This agreement was followed by a 79 billion Japanese yen loan to the Vietnamese government. The METI officials' efforts to export nuclear 
plants were vigorous. For the project in Vietnam, they competed against the Russians; for the United Arab Emirates project, they had to compete with South Koreans (DeWit and Iida 2011; Nanao 2011, 41). Obviously they believed that exporting nuclear technology would contribute to the state-sponsored industry where major stakeholders such as Mitsubishi, Toshiba, and Hitachi were involved.

Meanwhile, some technologists were innovators between the end of the 1990s and the first half of the 2000s (Yamaoka 2011, 195-96; Yoshioka 2011, 332). Their objective was the liberalization of the electric industry whereby nuclear power took a significant portion. In 1997, the cabinet decided that any electric company could establish sales companies. This decision was intended to make the electric market competitive and lower the customers' bills. In 2001, the METI innovators discussed the possibility of division of labor between production of electricity and its transmission. But the liberalization effort failed. From the beginning, it had limitations because METI did not intend to discard the longstanding state-sponsored policy toward the electric industry. The biggest obstacle was resistance from the existing electric companies, which were enjoying the monopoly of production, transmission, and sales in certain areas. The companies disputed liberalization, referring to the case of energy shortage in California in 2000 and 2001. The California problem occurred because the electricity producer, in order to keep the costs down, did not establish new facilities, but the high summer temperatures caused a supply shortage. The Japanese companies maintained that production, transmission, and sales should not be divided and that liberalization would certainly bring about a discrepancy between supply and demand.

\section{Institutional Drift, 2011-present}

The damage caused by the March 11 incident in Fukushima was enormous. At least 789 people died in relation to the nuclear power disaster, not to mention the unknown number of people who were exposed to radiation at the initial stage. More than 310,000 people had to leave their homes for the fear of both external and internal exposure to radiation (Dauer et al. 2011, 1431; Biello 2011, 81113). Statistics show that about 20,000 people left Fukushima Prefecture after the incident for various reasons (Kaneko 2012, 141). It is apparent that most of them left the prefecture because they were afraid of radiation, while others did so because of damage caused by the tsunami.

Even before the March 11 incident, an earthquake in July 2007 damaged TEPCO's Kashiwazaki-Kariwa nuclear plant and caused the shut-down of four reactors. But there was no learning from the 2007 incident. The government and TEPCO did not take additional safety measures to cope with earthquakes and tsunamis. In this regard, the March 11 incident as a whole was "man-made," as 
concluded by the independent report commissioned by the Diet (Nagata 2012).

Since the March 11 incident, nuclear power as an institution has drifted. The institutional impetus has conspicuously declined, if not disappeared. The antinuclear power movement has spread throughout Japanese society. Young people, housewives, labor union leaders, and middle-class workers have been the main participants in the rallies demanding an end to the nuclear power age. They have tried to dramatize the March 11 incident in order to sink nuclear power in Japan, calling for "exit from nuclear." Also, the anti-nuclear weapons activists, who had been mostly silent for a long period, led the protests against the government's nuclear policy. People have disseminated and obtained information not only through traditional media but also through websites that activists, scientists, and citizens have operated: for instance, Association for Citizens and Scientists Concerned about Internal Radiation Exposure, Citizens' Nuclear Information Center, and Gakujoho (Nuclear Information).

Given this increased level of criticism of nuclear power, defections began to appear from among the conservative politicians, the longstanding promoters of the nuclear industry, beginning in the summer of 2011 and up until the winter of 2012. The first group was composed of a few insurgents who believed that Japan should abolish its nuclear power project in the long run. Kan Naoto, prime minister at the time of the March 11 incident, represented this group. Edano Yukio, chief cabinet secretary, and some DPJ politicians supported Kan. The second group consisted of a few other insurgents who took advantage of the escalating public criticism of nuclear power to try to expand their political popularity and electoral base. Shiga Prefecture Governor Kada Yukio and former DPJ leader Ozawa Ichiro belonged to this group. They went along with the antinuclear power activists, upholding the slogan of "exit from nuclear" in the lower house elections in December 2012. In terms of integrity and robustness, the first and the second groups were never a threat to the institution of nuclear power.

The defections from among the conservative politicians, mentioned above, were proven temporary. The longtime promoters and symbionts, represented by Abe Shinzo, were successful in justifying the continued need for nuclear power. In May 2011, Kan Naoto asked the Chubu Electric Power Company to suspend one of the oldest plants, Hamaoka plant, which has been in operation since 1976 (Kyodo News 2012). Also, Kan declared that Japan would eventually eliminate nuclear energy. However, his declaration was short of details and determination. Furthermore, he later retracted his demand, saying that it was only his personal preference. Apparently Kan's declaration was his wishful thinking in times of heightened anti-nuclear power sentiment. In spite of this weakened position, hawkish conservatives such as Abe Shinzo, the then LDP head, criticized Kan's declaration, calling it an irresponsible statement without a solution. In this context, Noda, Kan's successor as prime minister, expressed his desire to maintain the present nuclear power industry while decreasing reliance on it, but not 
eliminating it altogether. The Noda cabinet, in September 2012, retreated from its position of calling for the closure of all nuclear plants by the 2030s. This planned closure, which would mean gradual elimination during the 2030s, was calculated based on the durability of the existing power plants. As shown in Figure 1, the latest plants started their operations in the mid-2000s, and thus their 30-year lifespan will end in the mid-2030s. A notable point is that the Keidanren, the important association of business groups in Japan, suddenly held a joint news conference to call for abandonment of the closure plan just one day before the Noda cabinet's retraction (Tabuchi 2012).

Meanwhile, the technologists in the government have proposed no alternatives to nuclear power as the main source of energy. Now they believe that the export of nuclear power plants can play an important part in the new economic development strategy. With the expansion of U.S.-India nuclear cooperation, as well as Japan-India cooperation, both the government and the manufacturing groups will continue to seek the survival of Japanese nuclear technology along that track. As Nohrstedt (2008) aptly notes, the strong actors adopt minor changes in the existing policy in response to civil activism's dramatizing efforts. To recapitulate, the critical juncture of the March 11 incident has had little impact on the persistence of the existing institution.

Meanwhile, there is a lonely struggle going on in business circles. Son Masayoshi, the CEO of Softbank, a telecommunication company, advocates for an alternative solution to the shortage of energy resources in Japan. Son established the Japan Renewable Energy Foundation after the March 11 incident, and he now promotes solar panels and wind power as the most promising renewable sources of electricity. He thus hopes to expand his business in this direction. It is worth noting that he is arguing that open competition in the electricity market is the condition for success in such innovations. He particularly stresses that market competition can be guaranteed only by ending the existing monopoly system with regard to the production and transmission of electricity (Johnston 2012). However, Son is fighting alone as the Keidanren, the most powerful business lobby organization, supports the existing electricity market.

\section{Conclusion}

Since the March 11 incident, the public mood in Japan has been bitterly critical of the nuclear power industry and of related government policies. Obviously nuclear power as an institution will not prosper as it has done in the past. It seems that the institution is drifting away from its earlier configuration. However, it is not exhausted yet, but persists. Nuclear power will not soon be replaced by anything else.

If one sees what has been changed and what has remained intact, one can 
appraise institutional momentum. On the one hand, the value of the institutionthat is, energy security-mostly remains, although it has not yet been fully achieved. On the other hand, the spirit of peaceful use of nuclear power has been replaced with the excessively ambitious pursuit of the full nuclear fuel cycle. The dominating actors, such as conservative politicians, MITI officials, and the electric companies, have successfully achieved the full nuclear fuel cycle.

Nuclear power in the past six decades has resulted in a competency trap of inefficiency. Despite this trap, most actors, except contesting anti-nuclear power activists, hold the view that the sunk costs are too high to consider replacing nuclear power. The dominating actors do not debate a possible alternative. Increasing public criticism is not sufficient-and perhaps it is impossible-to reverse the existing nuclear fuel cycle, which is now the core of today's nuclear power industry. The dominant actors take part in the institution of nuclear power as veto players to any displacement.

\section{Note}

This work was supported by National Research Foundation of Korea-Grant funded by the Korean Government (NRF-2010-361-A00017).

\section{References}

Adria, Marco. 2010. Technology and Nationalism. Montreal: McGill-Queen's University Press.

Aldrich, Daniel. 2008. Site Fights: Divisive Facilities and Civil Society in Japan and the West. Ithaca, NY: Cornell University Press.

Arima Tetsuo. 2008. Genbatsu, Shoriki, CIA: Kimitsubunsho de yomu Showa rimensi [Nuclear Power, Shoriki, and CIA: The Other Side of the Showa Period Viewed through Declassified Documents]. Tokyo: Shinchosha.

Biello, David. 2011. “Japan's Nuclear Crisis Renews Debate over Environment, Health, and Global Energy Use." Health Affairs 30 (5): 811-13.

Bijker, Wiebe E., and John Law. 1992. “General Introduction.” In Shaping Technology/ Building Society, eds. Wiebe E. Bijker and John Law. Cambridge, MA: MIT Press, $1-16$.

Burnie, Shaun, and Aileen Mioko Smith. 2001. “Japan's Twilight Zone.” Bulletin of the Atomic Scientists 57 (3): 58-62.

Chanlett-Avery, Emma, and Mary Beth Nikitin. 2009. "Japan's Nuclear Future: Policy Debate, Prospects, and U.S. Interests." CRS Report for Congress. February 19.

Cyranoski, David. 2001. "Referendum Stalls Japanese Nuclear Power Strategy." Nature 411 (June): 729.

Cyranoski, David. 2010. “Japan Plans Nuclear Power Expansion.” Nature 464 (April): 661.

Dauer, Lawrence, Pat Zanzonico, Michael Tuttle, Dennis Quinn, and William Strauss. 
2011. "The Japanese Tsunami and Resulting Nuclear Emergency at the Fukushima Daiichi Power Facility: Technical, Radiologic, and Response Perspectives." Journal of Nuclear Medicine 52 (9): 1423-32.

Dauvergne, Peter. 1993. "Nuclear Power Development in Japan: 'Outside Forces' and the Politics of Reciprocal Consent." Asian Survey 33 (6): 576-91.

DeWit, Andrew, and Iida Tetsunari. 2011. "The Power Elite and Environmental-Energy Policy in Japan." The Asia-Pacific Journal 9 (4/4): 1-18.

Dusinberre, Martin, and Daniel Aldrich. 2011. "Hatoko Comes Home: Civil Society and Nuclear Power in Japan." Journal of Asian Studies 70 (3): 683-705.

Fioretos, Orfeo. 2004. "Historical Institutionalism in International Relations." International Organization 65 (2): 367-99.

Furber, Robert, James Warf, and Sheldon Plotkin. 2008. "The Future of Nuclear Power." Monthly Review 59 (9): 38-48.

Hecht, Gabrielle. 2009. The Radiance of France. Cambridge, MA: MIT Press.

Hymans, Jacques. 2011. "Veto Players, Nuclear Energy, and Nonproliferation: Domestic Institutional Barriers to a Japanese Bomb." International Security 36 (2): 154-89.

Iida Tetsunari. 2011. "Genbatsu wo kanonishi, fukanonishita mono" [The Things That Make the Nuclear Power Plants Possible and Those That Make Them Impossible]. Gendai Shiso 39 (May): 88-94.

Ikenberry, G. John. 2001. After Victory: Institutions, Strategic Restraint, and the Rebuilding of the Order after Major Wars. Princeton: Princeton University Press.

Johnston, Eric. 2012. "Eliminating All Nuke Power Cheapest Option: Softbank's Son.” Japan Times, September 7.

Kaneko Masaru. 2012. "Isitsuna kukan no keizaigaku: Richi jichitai kara mita genbatsu mondai" [Heterogeneous Space Economics: The Problem of Nuclear Power Plants viewed from the Hosting Local Governments]. Sekai (August): 136-43.

Kim, Sung Chull. 2013. "Japan's Strategic Response to North Korea: Activistic Security Policy, Eroding Pacifism.” In Japan's Strategic Challenges in a Changing Regional Environment, eds. Purnendra Jain and Lam Peng Er. London and Singapore: World Scientific, 73-96.

Koide, Hiroaki. 2011. “The Truth about Nuclear Power: Japanese Nuclear Engineer Calls for Abolition." The Asia-Pacific Journal 9 (31/5): 1-9.

Kyodo News. 2012. "Kan Group Pushes Decommissioning of a Dozen Reactors." Japan Times, June 29.

Lidsky, Lawrence M., and Marvin M. Miller. 2002. "Nuclear Power and Energy Security: A Revised Strategy for Japan." Science and Global Security 10 (2): 127-50.

Mahoney, James, and Kathleen Thelen. 2010. "A Theory of Gradual Institutional Change." In Explaining Institutional Change: Ambiguity, Agency, and Power, eds. James Mahoney and Kathleen Thelen. Cambridge, MA: Cambridge University Press, 1-37.

March, James, and Johan Olsen. 1989. Rediscovering Institutions: The Organizational Basis of Politics. New York: Free Press.

McCormack, Gavan. 2011. "Hubris Punished: Japan as Nuclear State." The Asia-Pacific Journal 9 (16/3): 109-13.

Nagata, Kazuaki. 2012. “Nuclear Crisis Man-Made: Diet Panel.” Japan Times, July 6.

Nanao Kazuaki. 2011. Genbatsu kanryo [Nuclear Power Bureaucrats]. Tokyo: Soshisha.

NHK E-TV. 2012. “Tokushu: Kakugenryo saikuru meiso no kiseki” [Trace of the Deviated 
Nuclear Fuel Cycle]. Broadcasted on June 17, 10:00-11:30 p.m.

Nohrstedt, Daniel. 2008. "The Politics of Crisis Policymaking: Chernobyl and Swedish Nuclear Energy Policy.” Policy Studies Journal 36 (2): 257-78.

Onitsuka, Hiroshi. 2012. "Hooked on Nuclear Power: Japanese State-Local Relations and the Vicious Cycle of Nuclear Dependence." The Asia-Pacific Journal 10 (3/1): 1-12.

Paul, T. V. 2007. "The US-India Nuclear Accord: Implications for the Nonproliferation Regime." International Journal 62: 845-61.

Penney, Matthew. 2012. "Nuclear Nationalism and Fukushima." The Asia-Pacific Journal 10 (11/2): 1-25.

Pierson, Paul. 2000. "Increasing Returns, Path Dependence, and the Study of Politics." American Political Science Review 94 (2): 251-67.

Pierson, Paul. 2004. Politics in Time: History, Institutions, and Social Analysis. Princeton: Princeton University Press.

Reagan, Ronald. 1987. "Message to the Congress Transmitting the Japan-United States Nuclear Energy Cooperation Agreement.” November 9. www.reagan.utexas.edu/ archives/speeches/1987/110987e.htm (accessed September 28, 2012).

Suzuki Manami. 2006. Kakutaikokuka suru Nihon [Japan Becoming a Grand Nuclear State]. Tokyo: Heibonsha.

Tabuchi, Hiroko. 2012. “Japan, Under Pressure, Backs Off Goal to Phase Out Nuclear Power by 2040.” New York Times, September 20.

Tanaka, Yuki, and Peter Kuznick. 2011. "Japan, the Atomic Bomb, and the 'Peaceful Uses of Nuclear Power"' The Asia-Pacific Journal 9 (18/1): 1-9.

Thelen, Kathleen. 2004. How Institutions Evolve: The Political Economy of Skills in Germany, Britain, the United States, and Japan. Cambridge: Cambridge University Press.

Tolliday, Steven. 2012. “Crumbling Dream: Japan's Nuclear Quest, 1954-2011.” Business and Economic History 10: 1-12.

Toyoda Arisune. 2010. Nihon no genbatsu gijutshu wa sekai wo kaeru [Japanese Nuclear Power Technology Changes the World]. Tokyo: Sodensha.

Umebayashi Hiromichi. 2011. "Kutsushihai no karyu ni okareta 'heiwariyo"' ['Peaceful Use' Placed under the Military Rule]. Gendai Shiso 39 (May): 95-103.

Wittner, Lawrence W. 1997. Resisting the Bomb: A History of the World Nuclear Disarmament Movement, 1954-1970. Stanford: Stanford University Press.

Yamaoka Junichiro. 2011. Genbatsu to kenryoku [Nuclear Power Plants and Power]. Tokyo: Chikuma Shinsho.

Yoshida, Yasuhiko. 2000. "Nuclear Safety Issue Jars Japan to Reconsider Its Policy." Japan Quarterly 47 (1): 56-64.

Yoshioka Hitoshi. 2011. Genshiryoku no shakaisi [Social History of Nuclear Power]. Tokyo: Asahi Shimbun Shuppan.

Zwigenberg, Ran. 2012. "The Coming of a Second Sun: The 1956 Atoms for Peace Exhibit in Hiroshima and Japan's Embrace of Nuclear Power." The Asia-Pacific Journal 10 (6/1): $1-17$. 
Sung Chull Kim is Humanities Korea Professor in the Institute for Peace and Unification Studies at Seoul National University. He is the author of a number of books including North Korea under Kim Jong Il: From Consolidation to Systemic Dissonance (SUNY Press, 2006). He edited several books including Regional Cooperation and Its Enemies in Northeast Asia (Routledge, 2006, with Edward Friedman), Engagement with North Korea (SUNY Press, 2009, with David Kang), and State Violence in East Asia (University Press of Kentucky, 2013, with N. Ganesan). He has contributed numerous articles to academic journals including Systems Research and Behavioral Science, Eastern European Politics, and Development and Society. 